\title{
Change and Democratization in One-Party Systems
}

\author{
Harold F. Bass Jr., Ouachita Baptist University
}

This analysis of one-party systems in three different settings -- the American South, the Eastern Bloc, and the Third World -- ponders the circumstance that both interparty competition and intraparty competition among subparty components (organization, office, and electorate) are on the rise in all three settings. This bodes well for the chances of democracy in each setting, regardless of whether one expects to find democracy in between the parties, as Schattschneider did, or expects that democracy should order the parties internally, as classical democratic theorists do. The analysis also commends Southern leadership succession institutions (competitive primaries and run-offs) as devices for attaining democracy while still in the one-party mode, and credits broader, pervasive structural and politocultural features of the American polity for the workability of those institutions.

Political parties occupy a central place in the study of politics (Leiserson 1957). The thematic concern with "Building Democracy in One-Party Systems" affords opportunities to address two abiding issues confronting students of political parties, with particular attention to single-party systems. They are 1) the relationship between democracy and political parties, and 2) the power relationships among various structural components of party: office, organization, and electorate.

Our perspectives address three comparatively distinct settings, all currently in transition: the American South, the Eastern Bloc, and the Third World. Thus, our thoughts on building democracy can be organized on two levels: 1) within the existing single-party framework, and 2) amid developing party competition. After outlining a general framework for analysis, an additional concern of this paper will be to consider leadership selection lessons from the American South.

\section{Parties and Democracy}

Scholarship on political parties is replete with controversies surrounding the relationship between parties and democracy, as ably summarized in Scott and Hrebrenar $(1979,282-84)$. Modern political parties emerged in the latter part of the 18th century in large measure to link government leaders in a democratic fashion with a growing electorate. Virtually from the outset, questions arose about their democratic efficacy.

The crux of the debate has become the appropriate unit of analysis: the party or the polity. Does the search for democracy focus within the party, or on the contribution of the party to the character of the polity?

Each position has been ably articulated. In the latter part of the nineteenth century, elite theorists in Europe and progressive reformers in the United States began to criticize political parties as undemocratic in terms of their internal 
organization. From his European perspective, Ostrogorski (1964) perceived American political parties as corrupt organizations that stifled political participation. Michels' (1962) study of the German Social Democratic Party extended this anti-democratic argument by suggesting that the iron law of oligarchy would inevitably distance party leaders from the rank and file.

In the United States, progressive reformers asserting the validity of these critiques sought to rid the parties of their corrupt taint and make them more democratic. They did so in large measure by advocating the direct primary as a nominating device that would transfer that vital power from the party machines to the voters.

However, within American political science, a profound opposition arose against the progressive reforms that weakened party organization. Ironically, its proponents sought to promote "democracy" by attacking the ostensibly "democratic" position of the progressives. Its leading advocate, E.E. Schattschneider $(1942,1)$, steadfastly insisted that "political parties created democracy and that modern democracy is unthinkable save in terms of parties." In contrast to the progressives, he adamantly insisted that democracy is to be found in competition between the parties, rather than inside the party. Schattschneider's expansive democratic claims are at the heart of the doctrine of responsible party government embraced at mid-century by the APSA Committee on Political Parties (1950), which he chaired.

Such a system would feature the following five components. First, parties would come up with programs to which they would commit themselves. Second, parties would nominate candidates committed to these programs. Third, voters would perceive clear choices between or among the competing parties. Fourth, voters would authorize a party to govern. Fifth, the elected representatives of the party so authorized would demonstrate sufficient cohesion and discipline to implement the promised programs.

According to these criteria, American political parties were deemed irresponsible and ineffective in performing their democratic function. In the controversial wake of the committee report, American parties scholars have tended to back away from Schattschneider's extreme position (Kirkpatrick 1971). While acknowledging the vital contribution of party competition to democracy, they typically do not consider it fully sufficient for democracy. Moreover, the progressive impulse defining democracy in terms of popular participation in party decision-making strongly reasserted itself in academic sponsorship of the party reforms of the 1960s and 1970s. These developments suggest an attempt to synthesize the contending positions so as to define party democracy both within and between the parties.

Note that this brief discussion has spoken in the plural: parties. In what senses can democracy be associated with the single-party system? Following Schattschneider, one could argue that it cannot, by definition, given that inter-party competition is a necessary condition of democracy. 
Significantly, however, the one-party systems in the South, the Eastern Bloc, and the Third World all have claimed to be democratic, albeit in different ways. The Southern defense was two-fold: external and internal. Externally, opposition parties were allowed to and did organize and compete, though without notable success. The internal defense drew directly from progressive thought. The institution of the direct primary as a nominating device guaranteed popular participation in the process of leadership selection, thus meeting a fundamental criterion of democracy. The Eastern Bloc's claim derived from Lenin's conception of the party as the vanguard of the proletarian masses, acting on their behalf. The Third World's justification was couched in terms of nation-building and the requisite of unifying the citizenry behind a common purpose. The latter two especially viewed the party as the virtual representative of the society.

\section{Single-Party System Variations}

In analyzing one-party systems, two overlapping distinctions are commonplace. One contrasts authoritarian and pluralistic varieties (Emerson 1966). One-party authoritarian systems are relatively more revolutionary minded and ideologically committed; they tend to be more intolerant and antagonistic toward divisive elements; and they typically feature stronger and tighter organization. Derived from the Leninist model, they emerged as the norm throughout the Eastern Bloc, in Communist systems in the Third World, as well as in some nonCommunist Third World settings.

The pluralistic alternative allows opposition to be articulated and strives to achieve synthesis among party factions, accompanied by a comparatively less homogeneous and potent organization. Examples include the Southern systems, along with numerous Third World countries. With the benefit of hindsight, the Eastern Bloc systems may in fact have been more pluralistic than outside observers imagined.

The other distinction depends on whether the single-party tolerates organized external opposition. In a one-party dominant system, while the party allows opposition parties to form and compete, it invariably wins. This relatively pluralistic pattern was long the case in the South, and it endures in Mexico. In the alternative, the party systematically outlaws any organized opposition. This was the fashion in the Eastern Bloc and much of the Third World and tends to be associated with a more authoritarian setting.

In relating these distinctions to the earlier discussion of parties and democracy, utilizing criteria of participation and competition, we can obviously attribute a greater degree of democracy to the pluralistic systems than to the authoritarian ones. Similarly, the one-party dominant systems would appear to promote democratic possibilities not present when organized opposition is outlawed. 


\section{Origins, Development, and Decline}

Our three single-party settings demonstrate distinctive patterns of origin, development, and now, it appears, decline. In the American South, the single-party system gradually emerged after 1876, in the wake of long-established constitutional norms, electoral institutions, and party competition. The end of Reconstruction left the Republicans discredited and the Democrats (heretofore usually strong) overwhelmingly dominant. With rare exceptions, the one-party pattern prevailed at the presidential level until 1964; and its remnants yet endure in many Southern states and localities.

The establishment of the Leninist model in Russia in 1917 came in the midst of revolutionary turmoil. The traditional czarist autocracy, weakened by the wages of World War I, collapsed and was followed by a provisional government sympathetic to liberal democracy, but ineffective at establishing its authority. Lenin's Bolshevik Revolution supplanted the provisional government. Electoral institutions and party competition were exceedingly young and fragile; they were relatively easily suppressed. After World War II, the model was applied and maintained throughout Eastern Europe under the auspices of the Red Army that had marched west in opposition to Hitler's Germany. Here again, the model took root in societies not as steeped in democratic norms and values. In the late 1980s, these systems collapsed.

In a few Third World countries, notably China, Cuba, and Ethiopia, the Leninist model has been adopted by Marxist revolutionaries who have seized power. More prevalent in the Third World, however, are single-party systems that have emerged in the context of national independence. In assessing the "rise to self assertion of Asian and African peoples," Emerson called attention to "the erosion of democracy in the new states." His point of departure was the growing tendency of political leaders in the newly independent states either to circumvent or to turn entirely away from the structural trappings of democracy instituted by the colonial authorities. He identified two characteristic forms of erosion: "the seizure of power by the military and the turn to a one party system" (Emerson 1960, 282).

The party-state in the developing world was usually described as emerging from a perceived need for unity, for common identity, to promote national integration in the new state. The argument was that governments in the Third World could not afford the luxury of democratic opposition in this crucial period of nation building (Apter 1970). Thus, a single national party frequently emerged from pre-independence nationalist movements to take over and legitimize government structures, to control newly-expanded popular participation, and to implement economic development programs.

Such parties typically demonstrated antagonism toward other political organizations. Kilson's (1963) study of single-party evolution identified four analytically distinct patterns of reaction to inter-party opposition that, in practice, 
often concurred: 1) extra-parliamentary restrictions on opposition parties; 2) government dissolution or outlawry of opposition parties; 3 ) regroupment or a united front process; and 4) a voluntary merger of the opposition with the ruling party.

As noted earlier, the primary alternative to single-party systems in the Third World has been military regimes. In several instances, the latter have supplanted the former. However, contemporary observers of Third World political systems perceive a growing disenchantment with these anti-party models and concordant signs of appreciation for, and receptivity to, party competition (Legum 1990).

\section{Party Component Relationships}

Absent meaningful inter-party competition, considerations of party democracy inevitably focus on party component relationships. Students of political party structure are familiar with the analytical distinction of party in office, party organization, and party in the electorate (Sorauf \& Beck 1988, 9-11). Party in office refers to those individuals who hold public office under the banner of the party. Party organization pertains to those individuals who hold party office, as opposed to public office. These individuals comprise the machinery of the party, the party apparatus. Party in the electorate, a concept introduced by fellow panelist Ralph M. Goldman (Key 1964, 164), embraces those individuals who, with varying degrees of commitment, but primarily through their votes, support the party's candidates and causes. Our present concern is with the interrelationships among these three elements in single-party systems.

\section{The Southern Model}

Our three single-party settings demonstrate distinctive conceptions of this relationship. In the American South, the party was clearly and merely a means to an end, a vehicle ridden, so to speak, en route to political power. In linking the party in office directly with the party in the electorate via the direct primary, the system minimized the role and status of the party organization. Key $(1949,387)$ observed, "The bald fact is that in most of the South most of the time party machinery is an impotent mechanism dedicated largely to the performance of routine duties." The party in office effectively designated and controlled the occupants of positions in the party hierarchy. ${ }^{1}$ In turn, the party electorate directly authorized and held accountable the party nominees' occupancy of public office, with the general election serving only as a procedural formality.

The defenders of the quality of Southern democracy emphasized the competitive character of the primary nomination process, especially given the runoff provision which guaranteed in most states that the winner of the party nomination would be the choice of a majority of those voting. Critics questioned 
first whether the democratic criterion was met by the mere allowance of competition, or whether meaningful competition was in fact required. Doubters also pointed out that the presence of restrictions on electoral participation belied democratic pretensions.

\section{Leninist Models}

In contrast, the Leninist model subordinated both electorate and government to party organization. Lenin's modifications of Marxist thought focused on the relatively undeveloped elements of organization and leadership. Lenin added to Marxism a theory of the elite party as the organizer of proletarian revolution. In addition, after the revolution, that same party exclusively would direct both state and society toward the transformations Marx anticipated. Institutions of party and state were analytically separate, but it became commonplace for party officials to control, and occupy, public offices. Top-level party officials tightly controlled nominations to public offices; indeed, there frequently would be only one nominee per office. Moreover, party officials might exercise the prerogative to claim a public office. If not, however, the party officials closely monitored those who did occupy public office.

The claim of this model to be democratic was based on two foundations, electoral and organizational in character. Popular elections formally authorized those who held public office. Extraordinarily high voter turnout and virtually unanimous endorsement of the stipulated nominees justified claims of popular legitimation. Then too, the party organization allegedly operated under theoretical norms of democratic centralism, which called for those at each level to designate their representatives at the higher level. In turn, the policies determined by the higher-level officials were binding on the lower levels. Objections to these claims to democracy included the absence of competition at both the nomination and general election stages, and the subordination in practice of "democratic" to "centralism" in most regimes exemplifying the model.

Where the Southern model minimized the power of the party organization, the Leninist counterpart maximized it. Where the Southern model heightened the role of the party electorate, the analytical notion of a mass party electorate had no place in Lenin's elitist conception of party. In both settings, general elections were a facade, providing the electorate only an opportunity to ratify choices already made within the party.

\section{Third World Models}

The diverse single-party systems of the Third World are more difficult to stereotype in terms of internal power relationships. The present commentary will ponder only party-government relationships.

Students of Third World party-states have noted a general antipathy on 
the part of government leaders toward political parties, usually based on a perception of parties as divisive. This elite hostility toward political parties operates on two levels, directed first (as previously noted) toward other parties, and second toward the very party organizations utilized by these elites to achieve power.

Regarding this second level, the declining role of the party organization in the party-state, Wallerstein (1966) has developed an ironical scenario. His beginning premise is that presented above: the one-party system emerges in the quest for independence and in the subsequent quests for national integration and for legitimacy. Achieving stability often involves stifling or coopting opposition, enrolling civil servants in the party, and generally equating the party with the state or even elevating the party over the state. Thus, Kwame Nkrumah's $(1961,209)$ declaration that "Ghana is the CPP (Convention People's Party) and the CPP is Ghana" echoes the statism of not only the Leninist organizational model, but that of Louis XIV ("L'etat c'est moi") as well.

However, Wallerstein speculates, perhaps because of the totality of its identification with the state, the party begins to lose its revolutionary-nationalist identity and becomes less meaningful for its mass adherents. This is a fairly common organizational concomitant of goal achievement. In turn, as party leaders double as government leaders as well, the relative amount of time and effort they can devote to party activities diminishes. For them, maintenance of the party structure usually becomes secondary to the business of governing.

Further, as lower level party activists strengthen their positions and rise within the party to fill the vacuums left by those who have crossed over into the government, they -- and the party structure itself -- may come to be viewed as potential threats by government leaders who have virtually abdicated their roles in the party proper. The party, after all, and not the government, is initially instrumental in expanding and coordinating popular participation, and allegiance is not automatically transferrable. The attitudes of the government leaders toward the party grow increasingly negative, and efforts to stifle the perceived menace ensue. Thus, the one-party state effectively is transformed into a no-party state.

Wallerstein's hypothesis is only surmise. A significant counter-example occurred in Tanganyika in the aftermath of independence. Julius Nyerere led the pre-independence nationalist movement, the Tanganyika African National Union (TANU). Following independence, TANU became the governing party with Nyerere as prime minister. Shortly afterward, with his status intact and retaining de facto power, Nyerere resigned his office with the stated intention of devoting his resources to strengthening the party organization, particularly with regard to coordinating and facilitating communication between the center and the periphery (Emerson 1963).

This scenario for party organizational decline perhaps is more likely in the authoritarian than in the pluralistic systems, given that party organizations in 
the former are likely to be stronger, tighter, and thus potentially more threatening. On the other hand, the logic of the Leninist model demands domination of the party organization over the party in office.

Similarly, it seems likely that party-state leaders in pluralistic systems might be less suspicious of their looser and less potent party organizations. On the other hand, the experience of the solid South does encompass inattention, if not actual antipathy, toward party leadership responsibilities that begot party organization decay.

Note in passing that Wallerstein's hypothesis appears broadly relevant to the United States during its experience as a developing nation-state. This may be purely coincidental, or it may support the thesis that the American example has relevance for contemporary developing nations. Recall early American government leaders' regard for parties as divisive factions, as expressed in Federalist 10 and Washington's Farewell Address, as well as Thomas Jefferson's well-known ambivalence toward parties even while using one as a governing expedient. The obvious parallel between the anti-party spirit of our forefathers and that of the political leaders of today's developing nations suggests the hypothesis that nationalistic leaders of emerging states seeking to promote common identity and unity generally tend to distrust, and thus try to prevent the rise of, partisan institutions. From this perspective, the anti-party spirit American scholars see and often deplore in the Third World has antecedents in our own experience, even prior to the emergence of the Progressive movement (Hofstadter 1969).

\section{Leadership Succession: A Lesson from the South?}

Southern institutions and patterns of leadership succession might well serve as appropriate models for the other two single-party systems to follow as they try to democratize. While leadership succession is a critical issue facing any polity, much of the recent scholarly literature on leadership succession has focused on the one-party communist systems in the Soviet Union, Eastern Europe, and China (Harrison 1979, Bunce 1980, Bunce 1981, Brown 1982, Esherick and Perry 1983, Zaninovich 1983, Roeder 1985, Bunce \& Roeder 1986, Wilson and Ji 1990, Dittmer 1990). An abiding theme in this literature is the absence or weakness of regularized procedures. Throughout the Third World, the passing of the first generation of post-independence leaders called attention to the issue of leadership succession, as the ensuing instability illustrated the lack of procedures for such. Can the procedures developed by the Southern state political systems to deal with this problem be adapted to use by the emerging post-communist systems of Eastern Europe and the party-states of the Third World?

Roth and Wilson $(1976,116)$ identify two distinct components of succession, or the transfer of power: the transferral itself, and the accompanying legitimation of the new leaders. They note that in democratic systems elections provide the forum for leadership succession. Constitutions stipulate that these 
elections occur at periodic intervals, and may well limit tenure of office holders. Political parties typically play the key roles in recruiting new leaders. The elections provide the means of popular legitimation.

In a single-party system, the leadership succession process necessarily takes place entirely within the confines of the party. The Southern single-party experience can be said to have incorporated and combined these norms of party recruitment and electoral legitimation in reasonably democratic fashion. However, it must be noted that many aspects of these norms emanate from state constitutions that predated the establishment of one-partyism, while others were imparted from the federal constitution, and thus should be credited as much or more to the larger American political structure and culture that predated and pervaded the South.

One such practice was the regular, fixed schedule of general elections. Another was the convention that losing incumbents would honor the outcome of the elections. A third consisted of codified procedures for filling vacancies in public offices caused by death or resignations, by elevation of lesser officeholders, authorization of an appointment, or a special election. Fourth, Southern state constitutions adopted in the aftermath of the Civil War typically limited the tenure of the chief executive.

Such institutionalization of succession practices precluded much of the "undemocratic" behavior associated with leadership succession in single-party systems elsewhere. ${ }^{2}$ Because of these procedures, public office-holders in the South did not have the option of suspending elections. Nor could they ignore the election results and cling to power. Prescribed routines for filling vacancies forestalled "coups d'etat" and assassinations. The federal constitution guaranteed a republican form of government.

These "non-negotiable givens" were the pillars of the structural and cultural setting within which Southern one-partyism emerged. Within this proscribed environment, Democratic parties in the Southern states consciously adopted specific leadership succession procedures that did enhance the democratic character of the intraparty aspect of the process.

They did so first and foremost through the institution of the primary elections advocated by the progressive reformers. This electoral mechanism guaranteed a substantial measure of popular legitimation of office holders. A perhaps apocryphal statement attributed to Tammany Hall boss William Tweed runs, "I don't care who does the electing as long as I control who does the nominating." The primary granted to the voters the authority to designate the nominees who, in turn, were assured of becoming office holders. As Key (1949, 417) observes, "When single-party action determines the results of elections in advance, the logic of democracy requires a direct vote on nominees."

Moreover, since the gubernatorial primaries typically featured considerable competition, run-off provisions guaranteed that the winner of the party 
nomination would be the choice of a majority of the voters participating. Again, from Key, "Under one-party conditions, the logic of majority decision makes the run-off primary a concomitant of the direct primary."

Just as the primary weakened the party organization relative to the party in office through near elimination of the former's role in the nomination of the latter, so leadership succession within the party in office also has frequently entailed the same for the party organization. An incoming governor usually claimed as prerogative the naming of the state party chair. Thus, through its dominance of the nomination of the leaders of the party in office, the party in the electorate came to have an indirect impact upon the leadership of the party organization, as well.

Following Key, this paper submits that the Southern practices of the direct primary and the run-off primary were deliberately instituted to enable democracy in that setting. They mandated a popular voice in the transfer of party leadership on both official and organizational levels. The evident shortcomings of this endeavor notwithstanding, it nevertheless definitely enhanced the democratic character of leadership succession in the one-party South. Thus, the Southern contribution to the enterprise of democracy in a one-party setting consists principally of institutionalized assurances of not only popular participation in party nominations, but also that the nominee would be the choice of the majority of voters participating.

However, lest this evaluation appear too magnanimous, chronology does suggest that these Southern practices were less a voluntary commitment to initiate democracy than a necessary accommodation to facilitate democratic pretensions. In other words, because the American structural and cultural commitment to democracy predated the emergence of the single-party system, the latter was compelled to develop democratic features. Moreover, restrictions on participation, such as the poll tax, literacy test, and the white primary, severely disabled democratic claims.

In this light, the question arises, how might single-party systems in other settings benefit from this Southern example? The major lesson the Southern experience appears to offer for building democracy in single-party systems is to direct attention to the normative and structural foundations of the system, along with their interrelationships (Apter 1965, 9-10). Framed within democratic contours, the Southern single-party systems conformed in their development. Absent such foundations, a similar pattern of democratic development appears problematical at best.

Moreover, the Southern experience suggests the primacy of the focus on democracy within the polity over democracy within the party. Democratic polities encourage democratic parties. While the converse may well be equally valid, it does not appear to be a lesson from the South. Rather, this interpretation of the Southern experience as a guide to building democracy in one-party systems emphasizes the establishment of democratic norms, particularly regularized 
electoral institutions for leadership succession, with the expectation that, once established, the party will accommodate itself to them.

Does this counsel constitute an endorsement of the direct primary and the run-off we associate with the Southern one-party experience? Key views them as logical concomitants of one-party democracy. As reforms, they clearly moved the emerging Southern one-party systems toward conformity with extant democratic norms; and they merit commendation as appropriate features of one-party democracy. However, they are not panaceas to be embraced uncritically and universally. It is our contention that their application in the American South provided the superstructure, rather than the foundation, to that model's claim to one-party democracy. While popular elections provide the proper forum for leadership succession in democratic systems, the specific electoral institutions appear less significant than the democratic values undergirding them.

\section{Transformations}

All three single-party system settings are in the midst of momentous transformations. At this point, consider the implications for parties and democracy of the rise of the Republican party in the South. The emergence of party competition promises subtle alteration of intraparty power relationships. Recall the traditional weakness of party organization in the one-party South. Over the past quarter-century, Democratic state party organizations have become increasingly institutionalized. Indicators include permanent headquarters, paid staff, division of labor and specialization, and attention to organization building (Bibby, et al. 1983; Cotter, et al. 1984). It is difficult to escape the conclusion that the rise of the GOP as an electoral force has been a major factor in generating these changes. While the long-term significance of the invigoration of party organization is not clear, one can speculate that an institutionalized party organization might in the future be less deferential toward the party in office.

A diametrically different pattern appears in progress among the traditionally impotent Republicans, whose electoral fortunes are on the rise. Historically lacking a party in office and a noteworthy party in the electorate, the party organization monopolized the party label and such power as it carried. Recently, however, with programmatic and financial assistance from the Republican National Committee and the GOP House and Senate campaign committees (Bibby 1979; Conway 1983; Wekkin 1985), Republican state party organizations in the South have begun to develop many of the same features of institutionalization that have begun to characterize their Democratic counterparts. Nevertheless, as essays in this volume by Charles Bullock and Eric Mackey demonstrate, the growth of the GOP in the Southern electorate and in elective offices, respectively, has been even greater, which suggests a relative decline in the intraparty power of the party organization (Bass and Westmoreland 1984).

In the more competitive interparty environment, primary voter turnout is 
declining within the Democratic party and increasing for the Republicans. Republicans are utilizing the primary mechanism to conform to cultural expectations and to state election laws imposed in the past by the dominant Democrats. In turn, general election turnout is on the rise, as voters finally have choices to make in that setting.

The juxtaposition of emerging two-party competition and the abiding direct primary suggests that both schools of thought in the debate over whether to seek democracy within or between parties should be optimistic about politics in today's South. The primary maintains democracy within the party, while competition enhances democracy within the polity.

Meanwhile, a fascinating phenomenon appears to be occurring in the Eastern Bloc. Within the Communist parties, the heretofore dominant party organization is in decline. In the Soviet Union, Gorbachev's creation of a strong presidency, and the role of RSFR President (and ex-Communist) Boris Yeltsin in withstanding the CPSU-led coup that attempted to undo that presidency, both suggest the growing power of officeholders versus the party organization. More important than the efforts of elected officials to resist the coup, however, were those mounted by the masses. As in the fateful Autumn of 1989, the strongest of the forces for democratization was the popular tide sweeping upward, from the streets to the spires of power.

In short, the ruling Communist parties have lost their monopoly on governmental power. New parties that from the outset have sought electoral authorization have emerged to challenge and indeed vanquish the Communists in much of the former Eastern Bloc. Thus, as in the Southern setting mentioned above, not only the emergence of external competition but a restructuring of the balance of power among the three internal components of the party appears to be irreversibly underway in Eastern Europe.

Finally, in the Third World, where the single-party system flourished in the wake of national independence, that experiment is in disarray. The system failed to realize the advantages it promised. Today, a rising democratic tide is manifesting itself in an abandonment of the single-party state and a turn to interparty competition. Legum (1990) documents these exciting prospects.

Thus, in this last decade of the twentieth century, the single-party model is indeed undergoing transformation in the diverse settings it once dominated. The challenges of building democracy are now likely to occur without, rather than within, the single party. The relationship among the three intraparty components may come to be of less consequence as democracy between competing parties reduces the necessity and importance of democracy within the parties.

\section{Conclusion}

This analysis of one-party systems has addressed the competing democratic claims of three models: the American South, the Eastern Bloc, and the Third 
World. Its broad overview of the patterns of origin, development, decline, and intraparty relationships for these three models permits us to draw several conclusions about the future direction of politics in one-party systems. First of all, each of the three one-party settings examined here appears to be headed toward twoparty or multi-party competition. Second, power within the parties themselves, in all three one-party systems, appears to be slipping out of the grasp of the formerly dominant intraparty component.

Such developments have important theoretical ramifications for students of party democracy, as well as obvious political ramifications for citizens and political practitioners within those three milieux. First, the challenge of building democracy in these systems now lies increasingly outside of -- that is, in between -- the parties, rather than inside any one dominant party. Second, the intraparty power relationship among the political party's three component parts matters less, of course, in a system in which there is significant interparty competition than it did during the status quo ante. Proponents of both sides of the longstanding partydemocracy controversy, especially those who take Schattschneider's side, have to be pleased with such developments.

Finally, the special attention given here to the efficacy of established patterns of leadership succession in the South, and to the structural and politocultural requisites that give rise to such institutions, should demonstrate the extent to which political elites in each of these three settings might profit from greater knowledge of each other's experience of trying to operate democratic government in the absence of partisan competition. Scholars of political parties and their democratic roles have ever recited the need for more research of a comparative nature. Now, more than ever, in the context of democratic strivings of nearly global proportions, is the time to accelerate and intensify comparative research of each of these three one-party models, in the hope that all might profit from the trove of experience that can be aggregated and abstracted from the failures and successes of each model.

\section{NOTES}

${ }^{1}$ Consider, for example, the composition of the state executive committee of the Missouri Democratic Party in the early 1980's. Except for the usual state party officers (chair, vice chair, secretary, treasurer, and 6 national committee members), the rest of the executive committee consisted of Senator Thomas Eagleton, Lt. Governor Kenneth Rothman, Secretary of State James Kirkpatrick, State Treasurer Mel Carnahan, (state) Senate President Pro Tem Norman Merrell, (state) Speaker of the House Bob Griffin, U.S. Representative Richard Gephardt, State Representative Phil Curls, State Young Democrats' President Rusty Carnahan, one staffer each from Senator Eagleton's and Representative Gephardt's offices (to sit in for their bosses), and only five party members who held neither government nor party office. In contrast, Democratic parties in Northern states might formally allot one central committee seat per chamber to the party's legislative wing (as in Wisconsin), or none at all (as in Idaho and Montana). 
${ }^{2}$ Which is not to say that the urge to degrade the opposition did not manifest itself in certain practices, such as Arkansas' requirement that the parties reimburse the state for the costs of holding primary elections -- a way of narrowing access to (and thus interest in) the GOP primary.

\section{REFERENCES}

Apter, David. 1965. The Politics of Modernization. Chicago: University of Chicago Press. . 1970. Some Reflections on the Role of a Political Opposition in New Nations. In Irving Leonard Markovitz, ed., African Politics and Society. New York: Free Press.

Bass, Harold F. and Andrew Westmoreland. 1984. Parties and Campaigns in Contemporary Arkansas Politics. Arkansas Political Science Journal 5: 38-58.

Bibby, John F. 1979. Political Parties and Federalism: The Republican National Committee. Publius 10: 229-236.

, Cornelius P. Cotter, James L. Gibson, and Robert J. Huckshorn. 1983. Parties in State Politics. In Virginia Gray, Herbert Jacob, and Kenneth N. Vines, eds., Politics in the American States, 4th ed. Boston: Little, Brown.

Brown, Archie. 1982. Leadership Succession and Policy Innovation. In Archie Brown and Michael Kaser, eds., Soviet Policy in the 1980s. Bloomington: Indiana University Press.

Bunce, Valerie. 1980. The Succession Connection: Policy Cycles and Political Change in the Soviet Union and Eastern Europe. American Political Science Review 74: 966-77.

and Philip G. Roeder. 1986. The Effects of Leadership Succession in the Soviet Union. American Political Science Review 80: 215-24.

Committee on Political Parties, American Political Science Association. Toward a More Responsible Two-Party System. American Political Science Review 44: Supplement.

Cotter, Cornelius P., James L. Gibson, John F. Bibby, and Robert J. Huckshorn. 1984. Party Organizations in American Politics. New York: Praeger.

Dittmer, Lowell. 1990. Patterns of Elite Strife and Succession in Chinese Politics. China Quarterly 123: 405-30.

Emerson, Rupert. 1960. From Empire to Nation: The Rise to Self-Assertion of Asian and African Peoples. Boston: Beacon Press.

1963. Nation-Building in Africa. In Karl W. Deutsch and William J. Foltz, eds., Nation-Building. New York: Atherton.

. 1966. Parties and National Integration in Africa. In Joseph LaPalombara and Myron Weiner, eds., Political Parties and Political Development. Princeton: Princeton University Press.

Esherick, Joseph W., and Elizabeth J. Perry. 1983. Leadership Succession in the People's Republic of China: "Crisis" or Opportunity? Studies in Comparative Communism 16: 171-78.

Harrison, Richard W. 1979. The Question of Soviet Succession. Journal of Social and Political Studies 4: 99-122.

Hofstadter, Richard. 1969. The Idea of a Party System: The Rise of Legitimate Opposition in the United States, 1780-1840. Berkeley: University of California Press. 


\section{Change and Democratization in One-Party Systems}

Key, V.O., Jr. 1964. Politics, Parties, and Pressure Groups, 5th ed. New York: Crowell. , with the assistance of Alex ander Heard. 1949. Southern Politics in State and Nation. New York: Alfred A. Knopf.

Kilson, Martin L. 1963. Authoritarian and Single Party Tendencies in African Politics. World Politics 5: 262-94.

Kirkpatrick, Evron M. 1971. Toward a More Responsible Two Party System: Political Science, Policy Science, or Pseudo-Science? AmericanPoliticalScience Review 65: 965-990.

Legum, Colin. 1990. The Coming of Africa's Second Independence. The Washington Quarterly 13: 129-40.

Leiserson, Avery. 1957. The Place of Parties in the Study of Politics. American Political Science Review 51: 943-54.

Lipset, Seymour Martin. 1963. Political Man: The Social Bases of Politics. Garden City, N.Y.: Doubleday Anchor.

Michels, Robert. 1962. Political Parties. New York: Free Press.

Nkrumah, Kwame. 1961. I Speak of Freedom. New York: Praeger.

Ostrogorski, Moisei. 1964. Democracy and the Organization of Political Parties. Edited and abridged by S.M. Lipset. New York: Anchor.

Roeder, Philip G. 1985. Do New Leaders Really Make a Difference? Rethinking the Succession Question. American Political Science Review 79: 958-76.

Roth, David F., and Frank L. Wilson. 1976. The Comparative Study of Politics. Boston: Houghton Mifflin.

Schattschneider, E.E. 1942. Party Government. New York: Rinehart.

Scott, Ruth K., and Ronald J. Hrebenar. 1979. Parties in Crisis: Party Politics inAmerica. New York: Wiley.

Sorauf, Frank J., and Paul Allen Beck. 1988. Party Politics in America, 6th ed. Glenville, Illinois: Scott, Foresman.

Wallerstein, Immanuel. 1966. The Decline of the Party in Single-Party African States. In Joseph LaPalombara and Myron Weiner, eds., Political Parties and Political Development. Princeton: Princeton University Press.

Wekkin, Gary D. 1985. Political Parties and Intergovernmental Relations in 1984: Consequences of Party Renewal for Territorial Constituencies. Publius 15: 1937.

Wilson, I., and Y. Ji. 1990. Leadership by "Lines:” China's Unresolved Succession. Problems of Communism 39: 28-44.

Zaninovich, M. George. 1983. Yugoslav Succession and Leadership Stability. Studies in Comparative Communism 16: 179-90. 